\title{
FACTORS ASSOCIATED WITH THE INTEGRATED FAMILY HEALTH POST UTILIZATION IN SIDOARJO, EAST JAVA
}

\author{
Tri Ratih Agustina
}

\author{
Universitas Wijaya Kusuma Surabaya
}

\begin{abstract}
Background: Nutrition is an important public health problem in Indonesia. As many as $37.2 \%$ of children under five had stunting. Nutritional status affects morbidity, mortality, and quality of human resources. Therefore, nutritional status needs to be monitored. The nutritional status of infants at the integrated family health post (posyandu) can be monitored by looking at the number of children weighed/ the number of all children (D/ S) coverage. Based on health data of 2014, the coverage of D/ S in Sidoarjo regency was 60.4\%, in the work area of Puskesmas Kepadangan was 68.8\%, and in Jiken village was 53.1\%. One of the causes of the low numbers was the low utilization of posyandu by mothers and children under five. The purpose of the study was to analyze factors associated with the utilization of posyandu by mothers and children under five.

Subjects and Method: This was an analytic observational study with a crosssectional design. The data was conducted at Jiken Tulangan village, Sidoarjo, East Java, from November 2016 to April 2017. The source population was 112 mothers who had children aged 6 to 59 months. A sample of 88 children under five and their mothers was selected by purposive sampling. The dependent variable was posyandu utilization. The independent variables were age, education, employment status, knowledge, attitude, distance to posyandu, maternal and child health monitoring book ownership, family support, health personnel role, and community health worker's (CHWs) role. The data were collected by questionnaire and analyzed by Chi-square test.

Results: Posyandu utilization increased with higher maternal knowledge (OR= 4.28; $95 \% \mathrm{CI}=1.69$ to $10.86 ; \mathrm{p}=0.003)$, employed mothers $(\mathrm{OR}=4.18 ; 95 \% \mathrm{CI}=$ 1.68to $10.44 ; \mathrm{p}=0.003)$, positive maternal attitude $(\mathrm{OR}=3.70 ; 95 \% \mathrm{CI}=1.53$ to 8.95; $\mathrm{p}=0.006$ ), maternal and child health monitoring book ownership ( $\mathrm{OR}=$ 3.01; $95 \% \mathrm{CI}=1.26$ to $7.21 ; \mathrm{p}=0.022)$, strong family support $(\mathrm{OR}=3.80 ; 95 \% \mathrm{CI}=$ 1.57 to $9.23 ; \mathrm{p}=0.005)$, $\mathrm{CHW}$ 's role $(\mathrm{OR}=8.82 ; 95 \% \mathrm{CI}=2.90$ to $26.79 ; \mathrm{p}<0,001)$, health personnel support $(\mathrm{OR}=4.56 ; 95 \% \mathrm{CI}=1.85$ to $11.16 ; \mathrm{p}=0.002)$, and close distance to posyandu ( $\mathrm{OR}=2.78 ; 95 \% \mathrm{CI}=1.13$ to $6.81 ; \mathrm{p}=0.041)$.

Conclusion: Posyandu utilization is affected by knowledge, employment status, positive attitude, maternal and child health monitoring book ownership, strong family support, CHW's role, health personnel support, and distance to posyandu.
\end{abstract}

Keywords: posyandu utilization, knowledge, attitude, family support, CHW's role, health personnel support, distance, children under five

\section{Correspondence:}

Tri Ratih Agustina. Universitas Wijaya Kusuma, Jl. Dukuh Kupang 25/54, Dukuh Kupang, Dukuh Pakis, Surabaya 60225, Jawa Timur.Mobile: +62811372336. 